\title{
Spatial and temporal variations of
} dissolved organic carbon and inorganic carbon concentrations and $\delta^{13} \mathrm{C}$ in a peatland-stream continuum: implications of peatland invasion by vascular plants

S. Gogo ${ }^{1,2,3}$, P. Albéric ${ }^{1,2,3}$, F. Laggoun-Défarge ${ }^{1,2,3}$, S. Binet ${ }^{1,2,3}$, and A. Aurouet ${ }^{4}$

${ }^{1}$ Université d'Orléans, ISTO, UMR7327, 45071, Orléans, France

${ }^{2}$ CNRS/INSU, ISTO, UMR7327, 45071 Orléans, France

${ }^{3}$ BRGM, ISTO, UMR7327, BP 36009, 45060 Orléans, France

${ }^{4}$ GeoHyd, Parc technologique du Clos du Moulin, 45160 Olivet, France

Received: 5 March 2012 - Accepted: 6 March 2012 - Published: 20 March 2012

Correspondence to: S. Gogo (sebastien.gogo@univ-orleans.fr)

Published by Copernicus Publications on behalf of the European Geosciences Union.

Dissolved carbon concentrations in a peatland-stream continuum

S. Gogo et al.

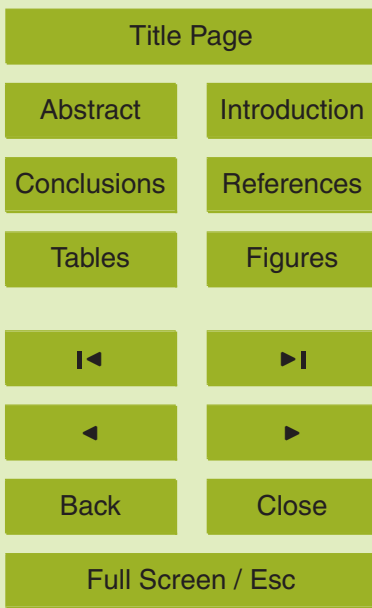

Printer-friendly Version 


\section{Abstract}

Dissolved fluxes of $\mathrm{C}$ which are an important component of the global $\mathrm{C}$ budget of peatlands may be affected by global change in different ways. The evolution of peatland vegetation is an issue caused by the indirect effect of global change that still needs

5 to be addressed. The aim of this study was to study the temporal and spatial variations in the quantity and the characteristics of dissolved $C$ within in a peatland stream continuum, the peatland being invaded by Molinia caerulea and Betula spp.

The study highlighted the following key points:

(i) Vegetation change tends to increase the DOC concentration of peat surface water.

(ii) DOC exports were in the range of those found in the literature, and it was clearly established that peatland DOC can reach second order streams.

(iii) Peat water was supersaturated in $\mathrm{CO}_{2}$ especially in summer during the peak of microbial activity.

(iv) the $\mathrm{CO}_{2}$ critical layer at the surface of the soil may promote $\mathrm{CO}_{2}$ excess build-up in the peat water. This critical layer may promote $\mathrm{CO}_{2}$ export out of the peatland.

The effect of vegetation change on the DOC content of peat water deserves further attention as it may have a deep impact on downstream river water quality. In particular, it is necessary to clarify whether the concentration of $C$ dynamics is affected by the invading species. More attention should be paid to hydrological processes (e.g. pumping capacity of the different plants) and the microbial activity in the rhizosphere of the invading plants. Also, the relation between the $\mathrm{CO}_{2}$ critical zone at the surface of the soil and the $\mathrm{CO}_{2}$ concentration in water should be studied in detail.

BGD

9, 3515-3544, 2012

Dissolved carbon concentrations in a peatland-stream continuum

S. Gogo et al.

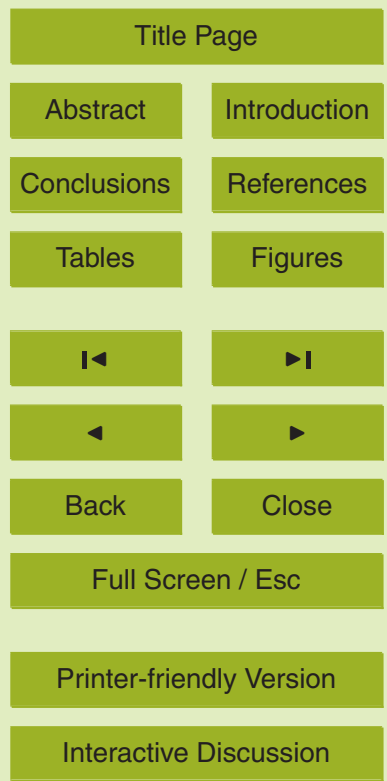




\section{Introduction}

Peatland ecosystems are the major natural continental carbon (C) store as well as an important $\mathrm{CH}_{4}$ source (Gorham, 1991). Their response to global change is uncertain, as positive or negative feedback can be triggered (Lashof et al., 1997). There is a need 5 to better assess and predict their $\mathrm{C}$ source or sink functioning to be able ultimately to take the peatland contribution into account in the global climate model (Limpens et al., 2008). To achieve this goal, $C$ budgets at the ecosystem level under different climatic conditions have to be monitored. Practically, each $\mathrm{C}$ input and output has to be quantified. Greenhouse gas $\left(\mathrm{CO}_{2}\right.$ and $\left.\mathrm{CH}_{4}\right)$ fluxes between peatland and atmosphere

10 are quantitatively the most important fluxes and, thus, the most frequently measured. This is particularly true for $\mathrm{CO}_{2}$ which can be monitored at high frequencies by eddy covariance techniques (Hendricks et al., 2010). These studies rarely measure fluxes of $C$ through dissolved forms. However, dissolved organic and inorganic $C$ (DOC and DIC respectively) fluxes from the peatland to downstream rivers can also represent 15 an important part of the ecosystem C budget (Worrall et al., 2003; Dinsmore et al., 2011). It is only recently that investigation into DIC and DOC export has received more attention (Billett and Moore, 2008; Dinsmore et al., 2009; Dinsmore et al., 2011). Many studies on stream water quality acknowledged that peatlands were present in the watershed and had an impact on the rivers' dissolved $C$ content. However, such studies did not always specifically investigate the characteristics of the water within the peatlands themselves (Telmer and Veizer, 1999; Dawson et al., 2004; Doctor et al., 2008). Thus, it seems relevant to study dissolved $C$ export in a peatland-stream continuum, rather than in streams alone, to better understand both the peatland $C$ budget and the river water quality.

25 Global changes, in addition to their direct effects, also modify peatland vegetation towards an increase in vascular plant contribution (Bubier et al., 2007; Limpens et al., 2008). The vascular plants affect soil organic matter dynamics (Mitchell et al., 2007; Gogo et al., 2011) and DOC production (Freeman et al., 2004 Gogo et al., 2012).
BGD

9, 3515-3544, 2012

\section{Dissolved carbon concentrations in a peatland-stream continuum}

S. Gogo et al.

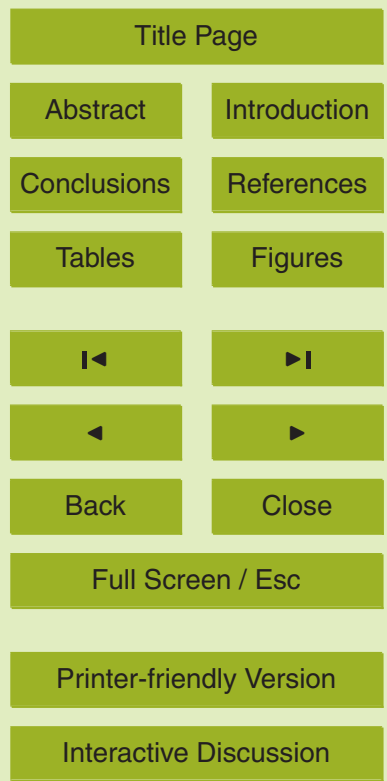


The quantity and the characteristics of the dissolved $\mathrm{C}$ within and exported out of the peatland may therefore be modified. This issue is particularly important as dissolved $C$ produced within the peatland undergoes biological transformation and experiences physico-chemical changes in the downstream river system that can affect the function-

5 ing of these systems and the water quality (Sachse et al, 2005). Furthermore, colonisation of peatlands by Molinia caerulea and Betula spp. is a current problem in many peat-accumulating systems (Tomassen et al., 2004). Thus, to tackle this issue, this study was undertaken in a peatland-stream continuum including a peatland colonized by these vascular plants: La Guette peatland.

10 The aims of this study were (i) to assess the extent of the influence of the peatland on the downstream hydrological system, (ii) to estimate the effect of vegetation change on dissolved $\mathrm{C}$ in peat water, (iii) to estimate the excess of $\mathrm{CO}_{2}$ partial pressure compared to the $\mathrm{CO}_{2}$ partial pressure of the atmosphere $\left(e p \mathrm{CO}_{2}\right)$ in order to identify hotspots of greenhouse gas outgassing. This was undertaken through the quantification of water 15 physico-chemical characteristics, DIC and DOC concentrations and $\delta^{13} \mathrm{C}$ in peatland water and first and second order streams, upstream and downstream of the peatland. The isotopic signature is a particularly powerful tool to trace $\mathrm{C}$ origin and processes.

\section{Materials and methods}

\subsection{Study site}

20 The site studied is La Guette peatland (Fig. 1). It is located in Neuvy-sur-Barangeon in the South-East part of the French Région Centre, $200 \mathrm{~km}$ south of Paris (altitude: $\left.160 \mathrm{~m}, \mathrm{~N}: 47^{\circ} 19^{\prime}, \mathrm{E}: 2^{\circ} 16^{\prime}\right)$. It is an acidic Sphagnum fen with low conductivity compared to the stream waters (Table 1). The dominant Sphagnum species are S. cuspidatum and $S$. rubellum. This site is experiencing a change in vegetation characterised by a switch in dominance from Sphagnum species in open vegetation plots to vascular plants (Molinia caerulea and Betula spp.) in the closed plots (Gogo et al., 2011).
BGD

9, 3515-3544, 2012

\section{Dissolved carbon concentrations in a \\ peatland-stream continuum}

S. Gogo et al.

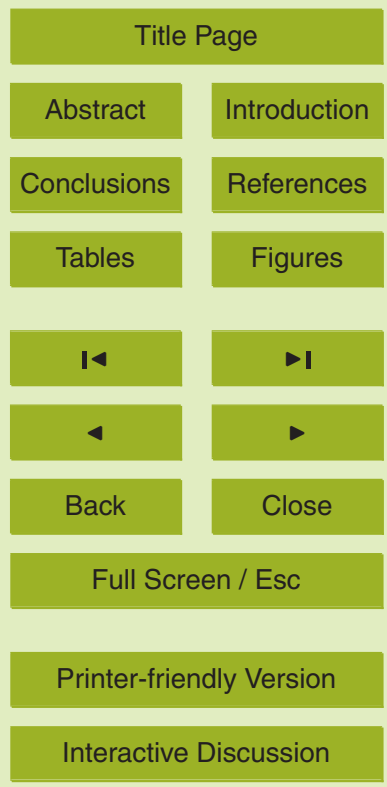




\subsection{Sample collection and conservation, climatic conditions}

Water was sampled at 16 different sites: 4 within the peatland (1, 2, 3 and 4 in Fig. 1), 5 on the fringe of the peatland corresponding to water drained out of the peatland $(6$, 7, 8, 9 and 10 in Fig. 1), 4 in first order streams relative to the peatland $(5,11,12$ and 513 in Fig. 1) and 3 in second order streams relative to the peatland (14, 15 and 16 in Fig. 1). At each sampling site and at each date, $\mathrm{pH}$, temperature and conductivity of the free water were measured with a multi-analyzer WTW 350i.

Within the peatland two sites were located in the western part: site 1 is dominated by open (without trees) vegetation and site 2 is dominated by Molinia caerulea and 10 especially Betula spp. vegetation, which tend to "close" the system. Two sites were located in the eastern part of the peatland: site 3 has open vegetation and site 4 has a closed vegetation cover (by Molinia caerulea and Betula spp). Site 5 corresponds to a drain going into the peatland. Water in this drain was only seen during the flooding event in May 2008. Site 6 collects water drained out of the peatland and corresponds to the limit between the peatland and the riparian zone surrounding the peatland. An intense sampling effort was made in the most intensive discharge area of the peatland: sites 7, 8, 9 and 10. Sites 11 and 12 correspond to the first order streams relative to the peatland and more precisely to the river La Guette. Site 13 can be assimilated to the outlet of the peatland as this stream receives the water of an artificial drain running parallel to the road D926 which collects water coming out of the sites 7, 8, 9 and 10. In a flooding event, such as during the first sampling date (May 2008), La Guette river and the drain along the road D926 can be connected. La Guette River and the peatland outlet flow into the second order stream, relative to the peatland, called the Barangeon. Site 14 corresponds to the upstream, site 15 is located after the confluence with La

Triplicate samples at each sampling location were collected at four different dates: 25 May 2008, 1 September 2008, 2 December 2008 and 9 March 2009. Note that the first collection was made during a flooding event. For DIC measurements, water was

\section{BGD}

9, 3515-3544, 2012

\section{Dissolved carbon \\ concentrations in a \\ peatland-stream \\ continuum}

S. Gogo et al.

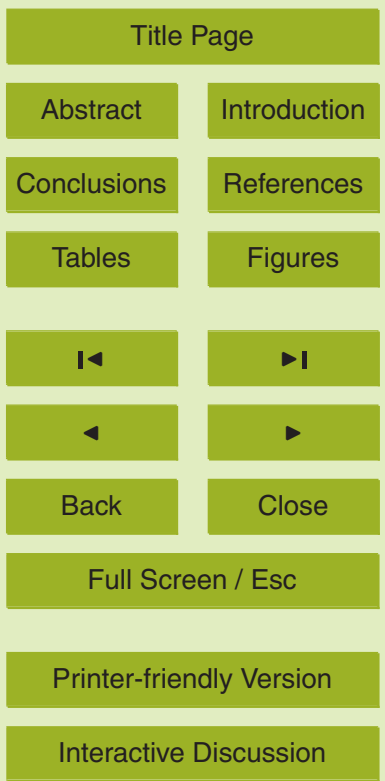


collected with a syringe mounted with a filter (pore size: $0.45 \mu \mathrm{m}$ ), filtered and stored at field in a $7 \mathrm{ml}$ headspace-free vial (Labco Exetainer). The tube was completely filled to obtain a convex water lens just above the edge of tube and closed with a screw cap mounted with a rubber septum. The flexibility of the rubber septum allowed water 5 from the lens to be kept within the tube. This prevented any air bubble from being trapped in the tube, which avoided air $\mathrm{CO}_{2}$ equilibration with the liquid phase. For DOC measurements, water was collected with a syringe mounted with a filter (pore size: $0.45 \mu \mathrm{m}$ ), filtered and stored in situ in a $12 \mathrm{ml}$ container (Falcon). Two drops of concentrated phosphoric acid were added to DOC samples within $24 \mathrm{~h}$ after collection. 10 All the samples were brought back to the laboratory and kept in the cold room $\left(4^{\circ} \mathrm{C}\right)$ until measurement.

\subsection{Dissolved Inorganic and Organic Carbon concentration measurement}

Dissolved Inorganic Carbon (DIC) concentrations were evaluated during the same run as DIC d13C analysis (see below) using the Thermo LC-Isolink interface coupled to a 15 Delta $\mathrm{V}$ isotopic ratio mass spectrometer (IRMS). Peak intensity was quantified versus $\mathrm{NaHCO}_{3}$ calibrating solutions.

Dissolved Organic Carbon (DOC) concentrations were determined using a Shimadzu $\left.{ }^{(}\right)$TOC 5000A total organic carbon analyzer, which is a high-temperature catalytic oxidation type of device with infrared detection, equipped with an ASI 5000A auto-sampler. DOC concentrations were measured in triplicate with a coefficient of variations better than $3 \%$.

\section{$2.4 \quad \delta^{13} \mathrm{C}$ of Dissolved Inorganic and Organic Carbon analyses}

Both DIC and DOC isotopic ratios were measured following the same procedure as that described by Albéric (2011) using the Thermo LC-Isolink IRMS interface. Each 25 run started by three monitor gas pulses $\left(\mathrm{CO}_{2}\right)$ for $\delta^{13} \mathrm{C}$ calculation. For DIC $\delta^{13} \mathrm{C}$ calibration, two standard solutions were prepared just before measurement by dissolving
BGD

9, 3515-3544, 2012

Dissolved carbon concentrations in a

peatland-stream continuum

S. Gogo et al.

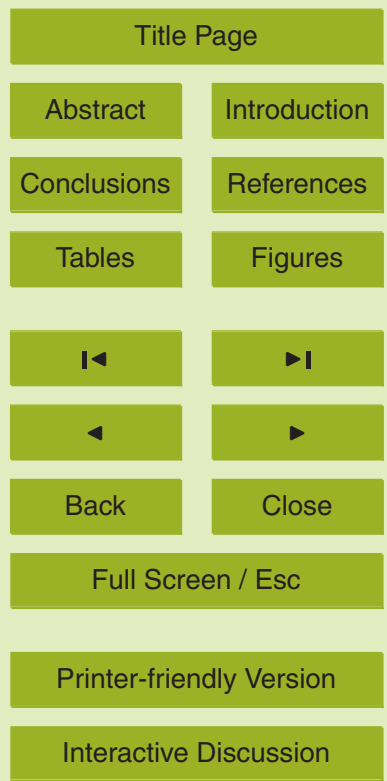


carbonate salts with degassed MilliQ water: LSVEC (Li carbonate) international standard with a $\delta^{13} \mathrm{C}$ of $-46.6 \%$ and a working (Na bicarbonate) standard with a $\delta^{13} \mathrm{C}$ of $-4.3 \%$. A calibration curve was calculated with the theoretical and measured values and the data were corrected using the equation obtained by linear regression. All the 5 samples were injected manually using the 6 way valve of the LC-Isolink interface fitted with a $100 \mu$ loop.

For DOC $\delta^{13} \mathrm{C}$ calibration was corrected against simple standard compounds: IAEACH6 (sucrose), IAEA-C6 (sucrose), IAEA-C8 (oxalic acid), and USGS- 40 (glutamic acid) between -26.6 and $-10.45 \%$. DOC $\delta^{13} \mathrm{C}$ of macromolecular natural humic sub10 stances (Suwannee River fulvic acid IHSS-1S101F; -27.6\%) was found to fit the calibration curves within $0.3 \%$ (Albéric, 2011). All the samples were acidified and $\mathrm{He}$ purged before autosampler injection and analysis (Albéric, 2011).

\subsection{Calculation of excess dissolved $\mathrm{CO}_{2}: e p \mathrm{CO}_{2}$}

Excess partial pressure of $\mathrm{CO}_{2}\left(e p \mathrm{CO}_{2}\right)$ is the ratio of the partial pressure of $\mathrm{CO}_{2}$ $15\left(p \mathrm{CO}_{2}\right)$ in water to the atmospheric $\mathrm{CO}_{2}$ partial pressure (Neal, 1988; Doctor et al., 2008). Measurement of $\mathrm{DIC}$, in situ $\mathrm{pH}$ and in situ temperature enable the calculation of $p \mathrm{CO}_{2}$ (Doctor et al., 2008; Steinmann et al., 2008):

$p \mathrm{CO}_{2}=\frac{C_{t}}{\left(1+\frac{K_{1}}{10^{-\mathrm{pH}}}+\frac{K_{1} K_{2}}{\left(10^{-\mathrm{pH}}\right)^{2}}\right) K_{H}}$

Where $C_{t}$ is the concentration of DIC, $K_{1}$ and $K_{2}$ is the first and second dissociation 20 constants of $\mathrm{H}_{2} \mathrm{CO}_{3}$ respectively, calculated from algebraic expressions (Telmer and Veizer, 1999), and $K_{H}$ is the Henry constant for $\mathrm{CO}_{2}$, corrected for temperature using the Van't Hoff equation. The atmospheric value of $\mathrm{CO}_{2}$ concentration used for the calculation was 378 ppm (Doctor et al., 2008).

\section{BGD}

9, 3515-3544, 2012

\section{Dissolved carbon concentrations in a peatland-stream continuum}

S. Gogo et al.

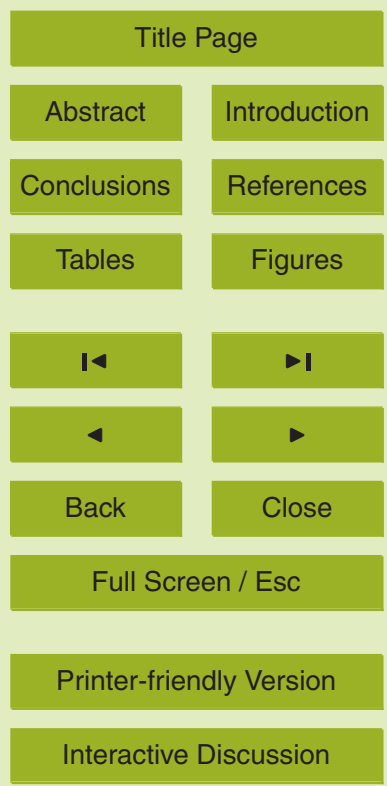




\subsection{Atmospheric $\mathrm{CO}_{2}$ concentration}

In May 2011, atmospheric $\mathrm{CO}_{2}$ concentration at different heights above three plots dominated by Molinia caerulea and Ericaceous shrubs was undertaken with a Vaisala Carbocap probe GMP 343.

\section{$5 \quad 2.7$ Statistics}

For each sampling plot and for each variable, the average of the three replicates collected was calculated. Then, averages were calculated and used to undertake statistical analyses. Paired $t$-tests were performed to assess differences between times within the peatland and the rivers. To test differences between vegetation types (open: plots 1 and 3; closed: plots 2 and 4), the multivariate Wilk test was performed. The significance level was set at 0.05 and $P$ values between 0.05 and 0.1 were considered to indicate a trend. When the averages of the variables were compared between dates, different letters indicate significant differences $(P<0.05)$. These tests were performed with Statistica (2008). Model II regression (Legendre and Legendre, 1998) was undertaken with an Excel macro.

\section{Results}

\subsection{Global trend of DIC and DOC concentrations and $\delta^{13} \mathrm{C}$}

In peatland water, both DIC and DOC concentrations were higher during summer than during the other seasons (Fig. 2a). Rivers tended to be richer in DIC and DOC during the flood event in May 2008 (Fig. 2b) than during the other seasons. DOC concentrations in peatland were always higher than in rivers (Fig. 2).

Within the peatland, waters collected in closed plots (invaded by Molinia caerulea and Betula spp.) tended to contain more DOC than in open plots (Table 2; Fig. 3a). The isotopic analysis showed that the DOC of the water collected in open plots tended

BGD

9, 3515-3544, 2012

Dissolved carbon concentrations in a peatland-stream continuum

S. Gogo et al.

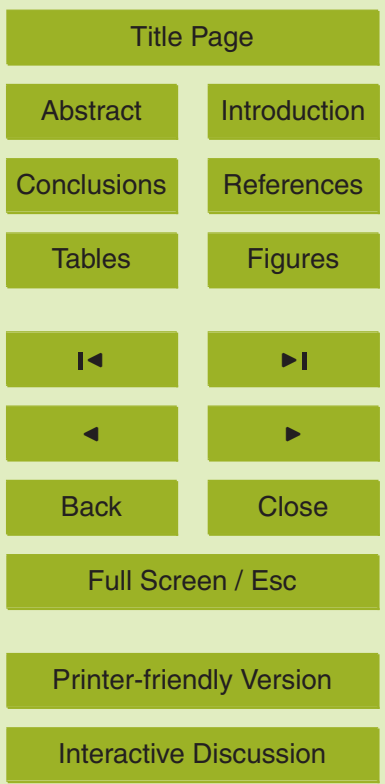


to be enriched in ${ }^{13} \mathrm{C}$ compared to the water collected in the closed plots (Table 1; Fig. 3b). For both DIC concentration and isotopic signature, no trends could be detected (Table 1).

\subsection{Seasonal patterns of $\mathrm{DOC} \delta^{13} \mathrm{C}$ and concentrations}

5 In spring (20 May 2008) and especially in summer (3 September 2008), the river DOC $\delta^{13} \mathrm{C}$ decreased from upstream to downstream (Fig. $4 \mathrm{a}$ and b). At these dates, but especially in September, the DOC in the Barangeon river (downstream) was nearly as depleted in ${ }^{13} \mathrm{C}$ as the DOC in peatland (respectively $-27.5 /-28.5 \%$ in spring, and $-27.0 /-28.0 \%$ in summer), whereas upstream, la Guette river contained DOC 10 relatively enriched in ${ }^{13} \mathrm{C}$ compared to all the other sampling locations at the same date $(-27 \%$ in spring and $-24.5 \%$ in summer, Fig. $4 a$ and b). In autumn (11 December 2008) and winter ( 3 March), the $\delta^{13} \mathrm{C}$ signatures of the DOC in rivers and peatland water were in the same range (Fig. $4 \mathrm{c}$ and d).

\subsection{Patterns of $\delta^{13} \mathrm{C}$-DIC, excess $p \mathrm{CO}_{2}$, and $\mathrm{CO}_{2}$ atmospheric concentration}

During the flood event in May 2008, waters from all streams and from all the peatland sites had relatively similar characteristics in terms of $\mathrm{CO}_{2}$ saturation and isotopic signature (Fig. 5a). Other than during the flood event, $\delta^{13} \mathrm{C}$ of the DIC of the la Guette and Barangeon rivers were distinctly higher than those of the peatland (Fig. 5b, c, d). At these dates, the $\delta^{13} \mathrm{C}$ signatures of the DIC of the outlet water were always closer to those of the peatland than those of the rivers (Fig. 5b, c, d). Pooling the data of all dates revealed a negative correlation between the isotopic signature of the DIC and the excess of $\mathrm{CO}_{2}$ in both rivers and peatland waters (Fig. 6). The outlet data were in an intermediate position between rivers and peatland data. The slope in the peatland was steeper than in the river. $\mathrm{CO}_{2}$ acidifies the water and as it leaves the water, and 25 the $\mathrm{pH}$ increases (Fig. 7). Air $\mathrm{CO}_{2}$ concentration was much higher just above the soil than in the air above (Fig. 8).
BGD

9, 3515-3544, 2012

Dissolved carbon concentrations in a

peatland-stream continuum

S. Gogo et al.

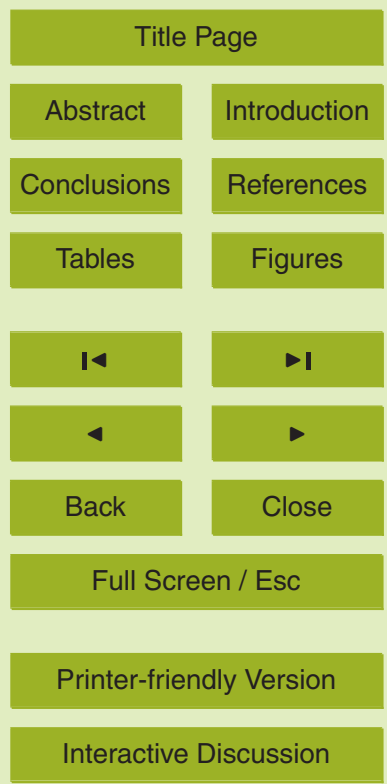




\subsection{Exported dissolved C fluxes}

Exported dissolved $\mathrm{C}$ fluxes were calculated using the concentrations in the water in the periphery of the peatland $(n=4)$ and in the outlet water $(n=1)$. The flux values used in the calculations were those of Binet et al. (2012). DOC export ranged from 12.6 to

$525.0 \mathrm{mg} \mathrm{h}^{-1} \mathrm{~m}^{-2}$ and DIC export ranged from 6.03 to $14.9 \mathrm{mg} \mathrm{h}^{-1} \mathrm{~m}^{-2}$ (Table 3). The only noteworthy differences between the two calculations were observed in September fluxes, with higher fluxes in the peatland data than the outlet data (Table 3).

\section{Discussion}

\subsection{Peatland DOC export}

10 La Guette peatland waters contained more DOC than the regional rivers. Thus, as already observed in other studies (e.g. Hemond, 1990; Kortelainen, 1999; Sasche et al., 2005), this peatland can be a potential source of DOC to downstream river systems. In this study, such an export was evidenced through the contrasted $\delta^{13} \mathrm{C}$ isotopic signature of the DOC in the La Guette river (upstream, location 11, red circle in Fig. 4) and 15 the Barangeon river (downstream, location 16, blue circle in Fig. 4). In May 2008 and September 2008, La Guette upstream river contained DOC enriched in ${ }^{13} \mathrm{C}$ compared to the DOC from the peatland sampling sites. Moreover, in the Barangeon downstream water, DOC was strongly depleted in ${ }^{13} \mathrm{C}$ and the isotopic signature was similar to that assessed for the peatland DOC. Elder et al. (2000) found that peatland vegeta20 tion was much more depleted in ${ }^{13} \mathrm{C}$ compared to aquatic plants (waterweed, flatstem pondweed) and algae. The DOC isotopic signature reported by Elder et al. (2000) actually reflected these differences in the sources, with a DOC- $\delta{ }^{13} \mathrm{C}$ of -28.2 and $-25.0 \%$ 。 in the streams influenced by the peatland and the valley ecosystems composed of submerged and aquatic plants, respectively. In upstream La Guette river, the $\delta^{13} \mathrm{C}$ depleted DOC observed during spring and especially summer could reflect the influence

BGD

9, 3515-3544, 2012

Dissolved carbon concentrations in a

peatland-stream continuum

S. Gogo et al.

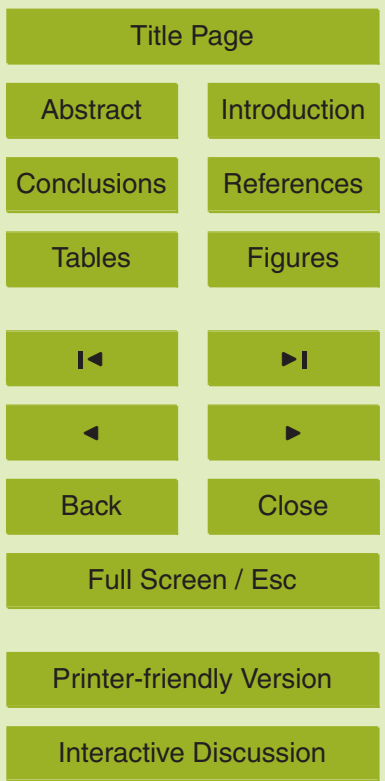


of aquatic vegetation growing in the river at these times. Such an influence was not observed in the Barangeon, although aquatic plants were also present. Thus, it can be inferred that, at least in May and September 2008, part of the DOC of the Barangeon downstream river originated from the La Guette peatland. Furthermore, the fluxes of 5 DOC estimated using the outlet data were the highest in December 2008 and March 2009. This suggests that the La Guette peatland is a substantial source of DOC to the downstream river system.

Peat solids do not exert a strong sorptive retention for DOC and, as water passes mainly through the very first centimetres of the peat profile, newly formed DOC through 10 decomposition in this layer can be efficiently transferred to the streams (Tipping et al., 2010). In May 2008, because of heavy rainfall, all the sampling sites were flooded. DOC concentration in the downstream Barangeon in May was the highest recorded in the river system during all time course of this survey $\left(14 \mathrm{mgl}^{-1}\right)$. This suggests that large amounts of DOC were rinsed out of the peatland to the downstream river system.

15 The DOC fluxes calculated with the peatland periphery data were dramatically higher than the fluxes calculated with the outlet data in September only (Table 3). A drain collects the water going out of the peatland and the outlet sampling point was located after this drain. The results suggest that a significant amount of DOC was either mineralised or precipitated through a flocculation reaction in the drain.

Thus, when we consider the DOC isotopic signature and concentration results together, the peatland could represent a major source of DOC not only to the first order stream, but also to the larger second order stream. At the moment, DOC exports out of the peatland are in the medium range of values found in the literature, such as those from Dyson et al. (2011) in Finnish peatland (between 21.7 and $42.4 \mathrm{mg} \mathrm{d}^{-1} \mathrm{~h}^{-1}$ ). Elder 25 et al. (2000) estimated lower DOC fluxes (between 3.2 and $15.1 \mathrm{mg} \mathrm{d}^{-1} \mathrm{~h}^{-1}$ ), whereas Clark et al. (2007) found much higher export fluxes (between 46.6 and $74.0 \mathrm{mg} \mathrm{d}^{-1} \mathrm{~h}^{-1}$ ). Any increase in DOC export from the peatland to the downstream river system can have important implications (i) for the $C$ budget estimation as punctual events can remove substantial amounts of $C$ from the peatland, (ii) in terms of water quality as any

\section{BGD}

9, 3515-3544, 2012

\section{Dissolved carbon concentrations in a peatland-stream continuum}

S. Gogo et al.

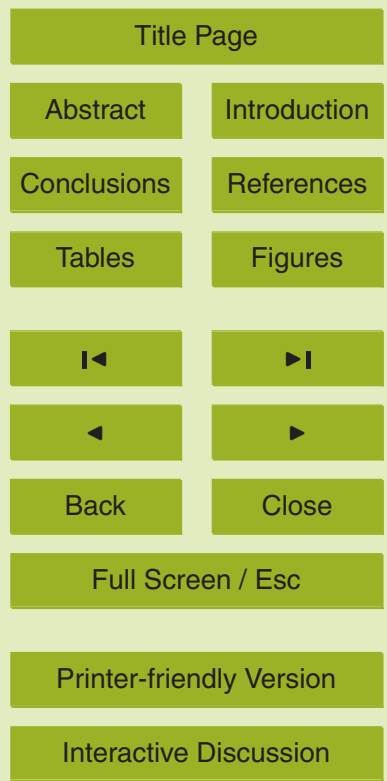


perturbation that promotes an increased concentration of DOC in the peatland would thus increase the DOC content in the downstream river system.

\subsection{Within peatland spatial variation of $\delta^{13} \mathrm{C}$ isotopic signature and concentration of DOC}

5 Water within the closed vegetation plots tended to have more DOC than waters from the open vegetation plots. Such a tendency could result from (i) a concentration through water uptake by invading plants, (ii) carbon dynamics promoting DOC accumulation, (iii) a combination of both processes. Untangling this issue is beyond the scope of this work. However it is worthy of interest as, in any case, a higher DOC concentration could originate from a modification in the functioning of the system caused by the invading species: perturbation of the water cycle and/or modification in the soil $\mathrm{C}$ dynamic.

Furthermore, DOC in open vegetation plots tended to be enriched in ${ }^{13} \mathrm{C}$ (compared to the closed vegetation plots). In La Guette peatland, the difference in vegetation is characterised by a switch in dominance from Sphagnum species in open vegetation plots to vascular plants (Molinia caerulea and Betula spp.) in the closed plots (Gogo et al., 2011). Compared to Sphagnum species, vascular vegetation litter contains less carbohydrates (Jia et al., 2008), a biochemical family known to have a higher $\delta^{13} \mathrm{C}$. In contrast to Sphagnum species, the vascular plant litter is composed of true lignin, which tends to be depleted in ${ }^{13} \mathrm{C}$ (Gleixner et al., 1993; Kracht and Gleixner, 2000; 20 van Dongen et al., 2002). Thus, the slight difference in $\delta^{13} \mathrm{C}$ may reflect the influence of the vegetation change on the DOC composition: the decomposition of the lignin rich vascular litter could lead to ${ }^{13} \mathrm{C}$ depleted DOC.

Although the composition and amount of DOC between open and closed vegetations tended to be different $(P<0.10)$, these results suggest that further effort should be devoted to confirm or infirm these tendencies. This is crucial as, if closed vegetation does indeed increase DOC concentrations, the vegetation change would ultimately increase the DOC export to downstream rivers.
BGD

9, 3515-3544, 2012

\section{Dissolved carbon concentrations in a \\ peatland-stream continuum}

S. Gogo et al.

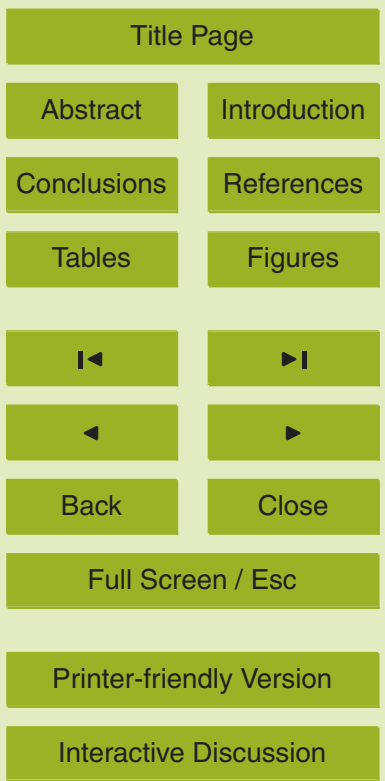




\subsection{Excess of $\mathrm{CO}_{2}$ in peatland waters}

Throughout the year, and especially in summer, water samples from the peatland (all plots taken together) were more supersaturated in $\mathrm{CO}_{2}$ than those from the rivers (Fig. 5). The higher $\mathrm{CO}_{2}$ supersaturation of peatland water during the summer cer5 tainly reflects higher microbial respiration activity during this season (Billett and Moore, 2008). Although in the same order of magnitude, the values of $e p \mathrm{CO}_{2}$ for peatland waters reported in this work were higher than those recorded by Billett and Moore (2008) in a North-American peatland. However, our values fall within the range of the Ottawa river basin soils $p$ CO2 calculated by Telmer and Viezer (1999). They unfortunately did 10 not detail the characteristics of the soils. As La Guette peatland experiences warmer conditions than Canadian peatlands, this higher temperature in the French site would promote microbial activity, which may explain the high $e p \mathrm{CO}_{2}$ measured in this study.

However, in addition to high microbial activity, another mechanism could contribute to generating such high excesses of dissolved $\mathrm{CO}_{2}$. We hypothesize that an air layer is maintained isolated from the atmospheric air by the vegetation and $\mathrm{CO}_{2}$ produced by the microbial biomass can accumulate in this layer. Following Henry's law, as the $\mathrm{CO}_{2}$ accumulates in the air just above the soil surface, $\mathrm{CO}_{2}$ would also accumulate in the water. This hypothesis was supported by measurements of $\mathrm{CO}_{2}$ concentrations in air above vegetation plots (dominated by Molinia caerulea and Ericaceous shrubs) and just above the soil (Fig. 8). These measurements, although done only once, clearly showed that such a $\mathrm{CO}_{2}$ rich air layer just above the soil does exist. Further measurement has to be done (i) to highlight the seasonal pattern of this layer, (ii) to assess whether such a layer exists in Sphagnum carpets, and (iii) to assess whether this critical zone is specific to histosols.

BGD

9, 3515-3544, 2012

\section{Dissolved carbon concentrations in a peatland-stream continuum}

S. Gogo et al.

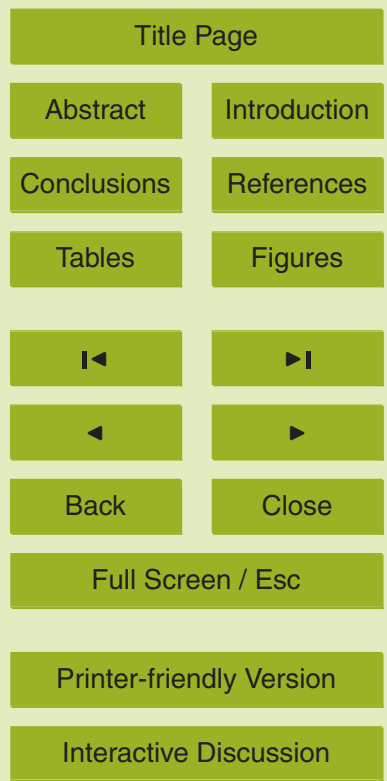




\subsection{Evidence of peatland- $\mathrm{CO}_{2}$ export in downstream river system}

Outgassing of excess $\mathrm{CO}_{2}$ in water could induce an isotopic fractionation, associated with the equilibrium between $\mathrm{CO}_{2}$ and $\mathrm{HCO}_{3}^{-}\left(\mathrm{HCO}_{3}^{-}\right.$being much more enriched in

${ }^{13} \mathrm{C}$ than $\mathrm{CO}_{2}$ ). This could result in a linear relationship between the natural Log of $5 e p \mathrm{CO}_{2}$ and $\delta^{13} \mathrm{C}$-DIC in stream waters (Doctor et al., 2008). Such a fractionation is assumed to occur when the $p \mathrm{CO}_{2}$ of the solution is greater than twice that of the atmosphere (Hendy, 1971). This situation actually occurs at all times in the streams and peatland waters, with some exceptions in December 2009. A relationship between epCO $\mathrm{CO}_{2}$ and $\delta^{13} \mathrm{C}$-DIC was found in both peatland and river water (Fig. 6). In streams, 10 for 1 natural Log unit decrease in $e p \mathrm{CO}_{2}, \delta^{13} \mathrm{C}$-DIC increased to $2.32 \%$. This is in the range observed by Doctor et al. (2008). Outgassing of this nature is supported by the significant relationship between $e \mathrm{CO}_{2}$ and the $\mathrm{pH}$. This relationship showed that in peatland water and direct tributaries, dissolved $\mathrm{CO}_{2}$ is a major control of water $\mathrm{pH}$. An increased flux of dissolved $\mathrm{CO} 2$ from the peatland to the proximal downstream system 5 would thus significantly affect the $\mathrm{pH}$.

In the peatland water, the relationship between $e p \mathrm{CO}_{2}$ and $\delta^{13} \mathrm{C}$-DIC was also significant, but the slope was much steeper than in streams and the regression explained less variablitity than in the case of stream waters. The same could be said for the relationship between $e p \mathrm{CO}_{2}$ and $\mathrm{pH}$ in river and peatland waters (Fig. 7). This probably 20 reflects a significant production and accumulation of ${ }^{13} \mathrm{C}$ depleted $\mathrm{CO}_{2}$ from microbial activity, with much less outgassing than in streams. This occurs especially during summer, when $\delta^{13} \mathrm{C}$-DIC was the closest to the corresponding $\delta^{13} \mathrm{C}$-DOC from which it proceeds through microbial assimilation and degradation, without much isotopic fractionation (Park and Epstein, 1961; Lin and Ehleringer, 1997). These results suggest tion of $\mathrm{CO}_{2}$ at the soil surface as described above, and accumulates in water.

Other than during the flood event, the DIC isotopic signature and the $e p \mathrm{CO}_{2}$ in the outlet water (location 13) were in the same range as those found in the peatland waters.

\section{BGD}

9, 3515-3544, 2012

\section{Dissolved carbon concentrations in a \\ peatland-stream continuum}

S. Gogo et al.

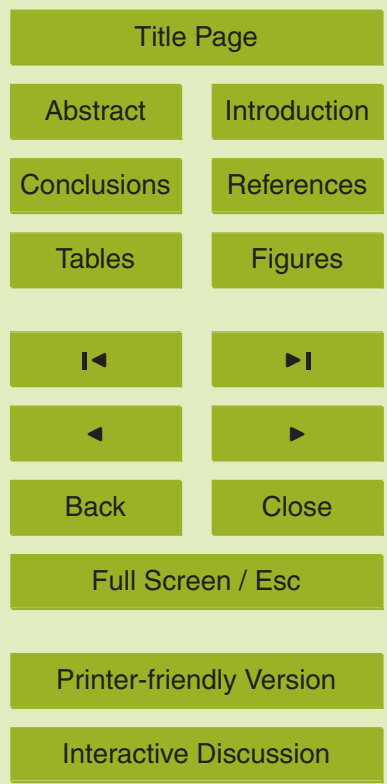


A few meters downstream, in the Barangeon river (location 16), the DIC isotopic signature decreased to values equivalent to those of the la Guette upstream river. The $e p \mathrm{CO}_{2}$ also decreased markedly. DOC results showed that in May and September, significant amounts of water from the peatland flood into the Barangeon river. Thus, in 5 terms of DIC, peatland water did not influence the Barangeon river. This suggests that a substantial amount of $\mathrm{CO}_{2}$ produced within the peatland is degassed just outside the peatland in the proximal downstream river. Such a process was particularly obvious in summer (Table 3 ), when $\mathrm{CO}_{2}$ produced by microbial activity accumulates in water more than during any other season. The outgassed flux through this pathway was estimated 10 to be about $10 \mathrm{mg} \mathrm{d}^{-1} \mathrm{~m}^{-2}$.

\section{Conclusions}

The results of this study suggest that both DIC and DOC produced within the peatland are exported to the downstream hydrological system. This means that, for the La Guette peatland, a $C$ budget based only on $C$ exchange between the soil and the 15 atmosphere would miss imported $\mathrm{C}$ fluxes. Dissolved exports were particularly high in summer for DIC and during the extreme flood event for DOC. Furthermore, the scope of the peatland influence on the downstream river system is greater in terms of DOC than DIC, because the latter is affected by the outgassing of $\mathrm{CO}_{2}$. DIC export may be promoted by the occurrence of a $\mathrm{CO}_{2}$ critical zone just at the surface of the soil that prevents the $\mathrm{CO}_{2}$ from being degassed within the peatland. The results highlighted that further work should focus on (i) the effect of the peatland vegetation change on both the amount and characteristics of DOC, and (ii) the effect of different vegetation on the gas concentration gradient in air above the soil, as this gradient may be crucial in determining the amount of DIC exported out of the system.
BGD

9, 3515-3544, 2012

\section{Dissolved carbon concentrations in a peatland-stream continuum}

S. Gogo et al.

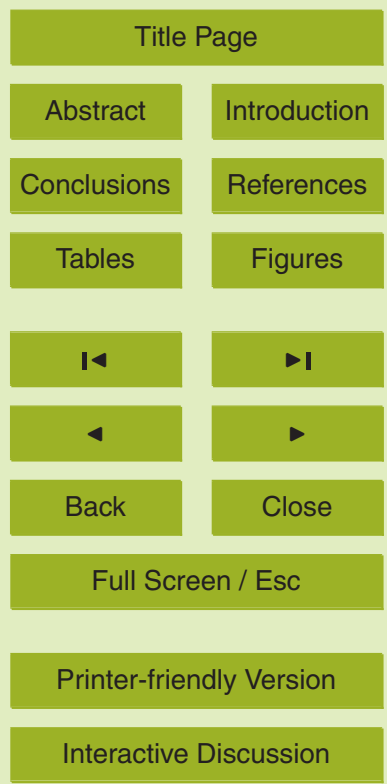


Acknowledgements. The authors would like to thank Emilie Rivoire and Nicolas Parou for their assistance during fieldwork. S. Gogo's salary was funded by the CG 45, the Spatioflux CPER research program (Resonat - FEDER) and the Labex VOLTAIRE.

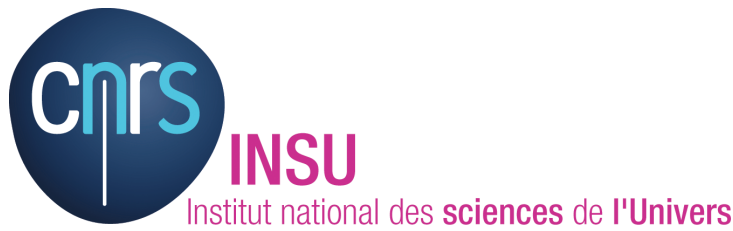

The publication of this article is financed by CNRS-INSU.

\section{References}

Albéric, P.: Liquid chromatography/mass spectrometry stable isotope analysis of dissolved organic carbon in stream and soil waters, Rapid Commun. Mass Spectrom., 25, 3012-3018, 2011.

Billett, M. F. and Moore, T. R.: Supersaturation and evasion of $\mathrm{CO}_{2}$ and $\mathrm{CH}_{4}$ in surface waters at Mer Bleue peatland, Canada, Hydrol. Process., 22, 2044-2054, 2008.

Binet, S., Gogo, S., Laggoun-Défarge, F., and Albéric, P.: Short-term impact of drainage on water balance in a peatland, in preperation, 2012.

15 Bubier, J., Moore, T. R., and Bledzki, L. A.: Effects of nutrient addition on vegetation and carbon cycling in an ombrotrophic bog, Glob. Change Biol. 13, 1168-1186, 2007.

Clark, J. M., Lane, S. N., Chapman, P. J., and Adamson J. K.: Export of dissolved organic carbon from an upland peatland during storm events: Implications for flux estimates, $\mathrm{J}$. Hydrol., 347, 438-447, 2007.

20 Dawson, J. J. C., Billett, M. F., Hope, D., Palmer, S. M., and Deacon, C. M.: Sources and sinks of aquatic carbon in a peatland stream continuum, Biogeochemistry, 70, 71-92, 2004.

Dinsmore, K., Skiba, U. M., Billett, M. F., and Drewer, J.: Spatial and Temporal variability in
BGD

9, 3515-3544, 2012

\section{Dissolved carbon concentrations in a peatland-stream continuum}

S. Gogo et al.

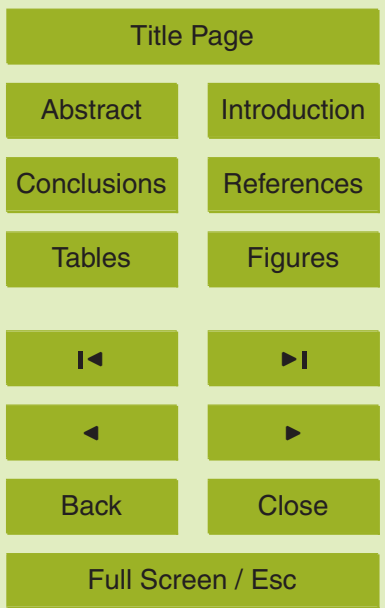

Printer-friendly Version

Interactive Discussion 
$\mathrm{CH}_{4}$ and $\mathrm{N}_{2} \mathrm{O}$ fluxes from a Scottisch ombrotrophic peatland: implications for modeling and upscalling, Soil Biol. Biochem., 41, 1315-1323, 2009.

Dinsmore, K., Billett, M. F., Dyson, K. E., Harvey, F., Thomson, A. M., Piirainen, S., and Kortelainen, P.: Stream water hydrochemistry as an indicator of carbon flow paths in Finnish 5 peatland catchments during a spring snowmelt event, Sci. Total Environ., 409, 4858-4867, 2011.

Doctor, D. H., Kendall, C., Sebestyen, S. D., Shanley, J. B., Ohte, N., and Boyer, E. W.: Carbon isotopic fractionation of dissolved inorganic carbon (DIC) due to outgassing of carbon dioxide from a headwater stream, Hydro. Process., 22, 2410-2423, 2008.

10 Dyson, K. E., Billett, M. F., Dinsmore, K. J., Harvey, F., and Thomson, A. M.: Release of aquatic carbon from two peatland catchments in E. Finland during spring snowmelt period, Biogeochemistry, 103, 125-142, 2011.

Elder, J. F., Rybicki, N. B., Carter, V., and Weintraub, V.: Sources and yields of dissolved carbon in northern Wisconsin stream catchments with differing amounts of peatland, Wetlands, 20, 113-125, 2000.

Freeman, C., Fenner, N., Ostle, N. J., Kang, H., Dowrick, D. J., Reynolds, B., Lock, M. A., Sleep, D., Hughes, S., and Hudson, J.: Export of dissolved organic carbon from peatlands under elevated carbon dioxide levels, Nature, 430, 195-198, 2004.

Gleixner, G., Danier, H. J., Werner, R. A., and Schmidt, H.-L.: Correlations between the ${ }^{13} \mathrm{C}$ content of primary and secondary plant products in different cell compartments and that in decomposing basiodiomycetes, Plant. Physiology, 102, 1287-1290, 1993.

Gogo, S., Laggoun-Défarge, F., Delarue, F., and Lottier, N.: Invasion of a Sphagnum-peatland by Betula spp and Molinia caerulea impacts on organic matter biochemistry, Implications for carbon and nutrient cycling, Biogeochemistry, 106, 53-69, 2011.

Gogo, S., Laggoun-Défarge, F., Merzouki, F., Dufour, A., Jozja, N., Delarue, F., and Défarge, C.: In situ and laboratory synergistic litter mixture effect on $\mathrm{C}$ dynamics of Sphagnum rubellum and Molinia caerulea litters, in preparation, 2012.

Gorham, E.: Northern peatlands: role in the carbon cycle and probable responses to climatic warming, Ecol. Appl., 1, 182-195, 1991.

30 Hemond, H. F.: Wetlands as a source for DOC to surface waters, in: Organic acids in aquatic systems, edited by: Perdue, E. M., Gjessing, E. T., Wiley, Chichester, 301-313, 1990.

Hendriks, D. M. D., van Huissteden, J., and Dolman, A. J.: Multi-technique assessment of spatial and temporal variability of methane fluxes in a peat meadow, Agr. For. Meteorol.,
BGD

9, 3515-3544, 2012

\section{Dissolved carbon \\ concentrations in a \\ peatland-stream \\ continuum}

S. Gogo et al.

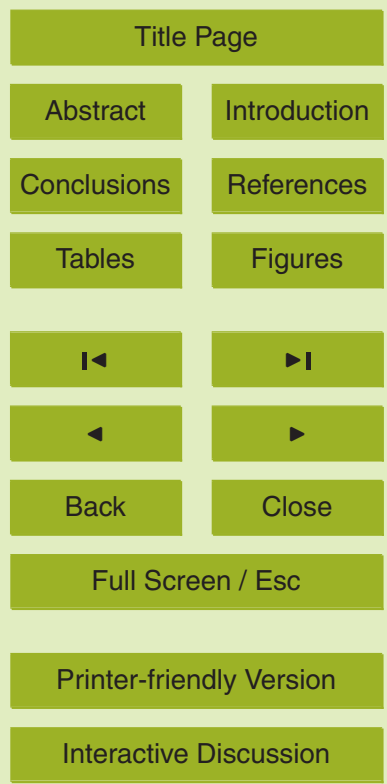


150, 757-774, 2010.

Hendy, C. H.: The isotopic geochemistry of speleothems - I. The calculation of the effects of different modes of formation on the isotopic composition of speleothems and their applicability as paleoclimatic indicators, Geochim. Cosmochim. Ac., 35, 801-824, 1971

5 Jia, G., Dungait, A. J., Bingham, E. M., Valirinta, M., Korhola, A., and Evershed, R. P.: Neutral monosaccharides as biomarker proxies for bog-forming plants for application to paleovegetation reconstruction in ombrotrophic peat deposits, Org. Geochem., 39, 1790-1799, 2008.

Kortelainen, P.: Content of total organic carbon in Finnish lakes and its relationship to catchment characteristics, Can. J. Fish. Aquat. Sci., 50, 1477-1483, 1993.

10 Kracht, O. and Gleixner, G.: Isotope analysis of pyrolysis products from Sphagnum peat and dissolved organic matter from bog water, Org. Geochem., 31, 645-654, 2000.

Lashof, D. A., DeAngelo, B. J., Saleska, S. R., and Harte, J.: Terrestrial ecosystem feedbacks to global climate change, Annu. Rev. Energ. Env., 22, 75-118, 1997.

Legendre, P. and Legendre, L.: Numerical Ecology, Elsevier Science B.V., Amsterdam, 1998.

15 Limpens, J., Berendse, F., Blodau, C., Canadell, J. G., Freeman, C., Holden, J., Roulet, N., Rydin, H., and Schaepman-Strub, G.: Peatlands and the carbon cycle: from local processes to global implications - a synthesis, Biogeosciences, 5, 1475-1491, doi:10.5194/bg-5-14752008, 2008.

Lin, G. and Ehleringer, J. R.: Carbon isotopic fractionation does not occur during dark respiration in C3 and C4 plants, Plant. Physiol., 114, 391-394, 1997.

Mitchell, R. J., Campbell, C. D., Chapman, S. J., Osler, G. H. R., Vanbergen, A. J., Ross, L. C., Cameron, C. M., and Cole, L.: The cascading effects of birch on heather moorland: a test for top-down control of an ecosystem engineer, J. Ecol. 95, 540-554, 2007

Neal, C.: Determination of dissolved $\mathrm{CO}_{2}$ in upland streamwater, J. Hydrol., 99, 127-142, 1988.

Park, R. and Epstein, S.: Metabolic fractionation of $\mathrm{C}^{13}$ and $\mathrm{C}^{12}$ in plants, Plant. Physiol., 36, 133-138, 1961.

Sachse, A., Henrion, R., Gelbrecht, J., and Steinberg, C. E. W.: Classification of dissolved organic carbon (DOC) in river systems: Influence of catchment characteristics and autochthonous processes, Org. Geochem., 36, 923-935, 2005.

Statsoft Inc.: STATISTICA for Windows Version 8.0. Tulsa Oklahoma, Statsoft, Inc, 2008.

Steinmann, P., Eilrich, B., Leuenberger, M., and Burns, S. J.: Stable carbon isotope composition and concentrations of $\mathrm{CO}_{2}$ and $\mathrm{CH}_{4}$ in the deep catotelm of peat bog, Geochim. Cosmochim.

\section{BGD}

9, 3515-3544, 2012

\section{Dissolved carbon \\ concentrations in a \\ peatland-stream \\ continuum}

S. Gogo et al.

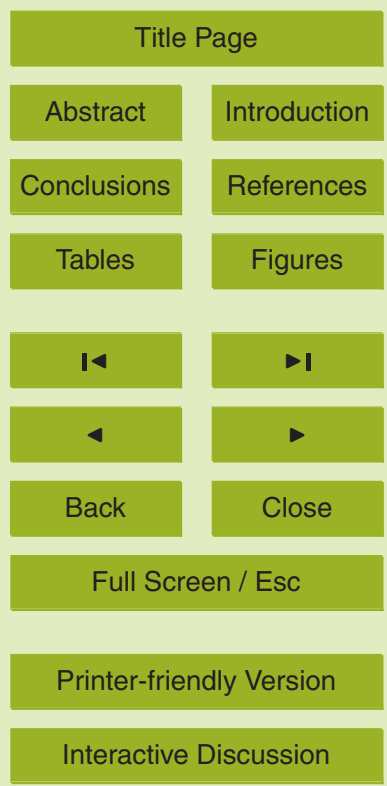


Ac., 72, 6015-6026, 2008.

Telmer, K. and Veizer, J.: Carbon fluxes, $\mathrm{pCO}_{2}$ and substrate weathering in a large northern river basin, Canada: carbon isotopes perspectives, Chem. Geol., 159, 61-86, 1999

Tipping, E., Billett, M. F., Bryant, C. L., Buckingham, S., and Thacker, S. A.: Sources and ages of dissolved organic matter in peatland streams: evidence from mixture modeling and radiocarbon data, Biogeochemistry 100, 121-137, 2010.

Tomassen, H. B. M., Smolders, A. J. P., Limpens, J., Lamers, L. P. M., and Roelofs, J. G. M.: Expansion of invasive species on ombrotrophic bogs: desiccation or high $\mathrm{N}$ deposition? J. Appl. Ecol., 41, 139-150, 2004.

10 van Dongen, B. E., Schouten, S., and Sinninghe Damsté, J. S.: Carbon isotope variability in monosaccharides and lipids of aquatic algae and terrestrial plants, Mar. Ecol.-Prog. Ser., 232, 83-92, 2002.

Worrall, F., Reed, M., Warburton, J., and Burt, T.: Carbon budget for a British upland peat catchment, Sci. Total Environ., 312, 133-146, 2003.

\section{BGD}

9, 3515-3544, 2012

\section{Dissolved carbon concentrations in a peatland-stream continuum}

S. Gogo et al.

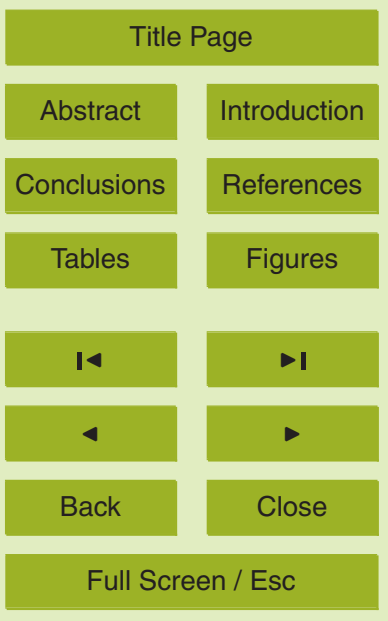

Printer-friendly Version

Interactive Discussion 


\section{BGD}

9, 3515-3544, 2012

Table 1. Annual average $(n=4)$ of $\mathrm{pH}$ and conductivity $\left(\mu \mathrm{S} \mathrm{cm}^{-1}\right)$ of the peatland and river waters.

\begin{tabular}{llll}
\hline Number Fig. 1 & Sampling station & $\mathrm{pH}$ & Conductivity \\
\hline 1 & West Open & $3.98 \pm 0.21$ & $49.0 \pm 6.47$ \\
2 & West Close & $3.73 \pm 0.22$ & $65.0 \pm 9.36$ \\
3 & East Open & $4.03 \pm 0.34$ & $51.9 \pm 8.25$ \\
4 & East Close & $3.93 \pm 0.23$ & $63.9 \pm 12.6$ \\
& & & \\
5 & Drain in 1 & 4.63 & 23.0 \\
6 & Drain out 1 & $4.62 \pm 0.22$ & $42.8 \pm 5.33$ \\
7 & Drain out 2 & $4.64 \pm 0.34$ & $40.2 \pm 6.25$ \\
8 & Drain out 3 & $4.69 \pm 0.45$ & $53.6 \pm 5.93$ \\
9 & Drain out 4 & $4.16 \pm 0.35$ & $54.3 \pm 10.4$ \\
10 & Drain out 5 & $5.56 \pm 0.43$ & $49.6 \pm 5.82$ \\
& & & \\
11 & La Guette upstream & $6.35 \pm 0.38$ & $147 \pm 22.7$ \\
12 & La Guette downstream & $6.41 \pm 0.33$ & $136 \pm 25.6$ \\
13 & Peatland outlet & $6.15 \pm 0.11$ & $76.6 \pm 19.2$ \\
& & & \\
14 & Barangeon upstream & $7.24 \pm 0.65$ & $199 \pm 28.0$ \\
15 & Barangeon downstream 1 & $7.04 \pm 0.42$ & $200 \pm 28.5$ \\
16 & Barangeon downstream 2 & $6.91 \pm 0.24$ & $186 \pm 35.5$ \\
\hline
\end{tabular}

\section{Dissolved carbon concentrations in a peatland-stream continuum}

S. Gogo et al.

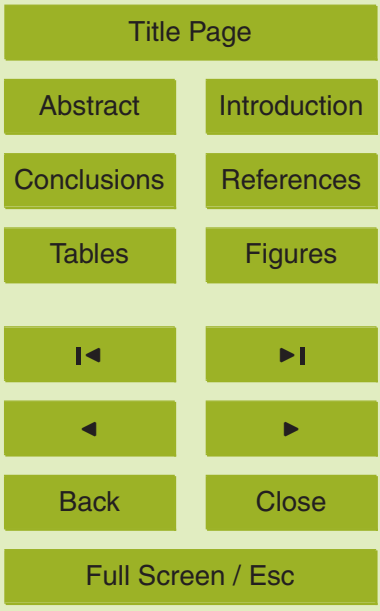

Printer-friendly Version

Interactive Discussion 
BGD

9, 3515-3544, 2012

\section{Dissolved carbon} concentrations in a peatland-stream continuum

S. Gogo et al.

Table 2. Results of the Wilk test on the vegetation effect on [DOC], $\delta^{13} \mathrm{C} \mathrm{DOC,} \mathrm{[DIC]} \mathrm{and} \delta^{13} \mathrm{C}$ DIC.

\begin{tabular}{lllll}
\hline & Wilk test value & $\mathrm{F}$ & $\mathrm{df}$ & $P$ \\
\hline [DOC] & 0.005 & 105 & 1 & 0.07 \\
$\delta^{13} \mathrm{C}$ DOC & 0.003 & 147 & 1 & 0.06 \\
& & & & \\
{$[\mathrm{DIC}]$} & 0.47 & 0.57 & 1 & 0.68 \\
$\delta^{13} \mathrm{C}$ DIC & 0.52 & 0.47 & 1 & 0.72 \\
\hline
\end{tabular}

Title Page

Abstract Introduction

Conclusions References

Tables Figures

14

Back

Close

Full Screen / Esc

Printer-friendly Version

Interactive Discussion 


\section{BGD}

9, 3515-3544, 2012

\section{Dissolved carbon concentrations in a \\ peatland-stream \\ continuum}

Table 3. DOC and DIC export out of the peatland fluxes $\left(\mathrm{mg} \mathrm{d}^{-1} \mathrm{~m}^{-2}\right)$ estimated using the mean DOC concentrations of the water at the periphery of the peatland $(n=4)$ and the DOC concentrations of the outlet water $(n=1)$. The water flow values used in the calculations were those of Binet et al. (2012). $\Delta$ corresponds to the difference between fluxes estimated with peatland periphery data and fluxes estimated with outlet data.

\begin{tabular}{lllll}
\hline & & Peatland periphery & Outlet & $\Delta$ \\
\hline DOC & May 2008 & $12.6 \pm 0.68$ & 11.8 & 0.83 \\
& September 2008 & $25.0 \pm 4.67$ & 7.61 & 17.4 \\
& December 2008 & $19.8 \pm 6.03$ & 14.5 & 5.28 \\
& March 2009 & $20.8 \pm 5.00$ & 21.6 & -0.76 \\
DIC & May 2008 & $6.03 \pm 0.91$ & 8.01 & -1.98 \\
& September 2008 & $14.9 \pm 2.61$ & 4.4 & 10.5 \\
& December 2008 & $5.86 \pm 1.60$ & 5.98 & -0.11 \\
& March 2009 & $6.86 \pm 0.83$ & 8.94 & -2.09 \\
\hline
\end{tabular}

S. Gogo et al.

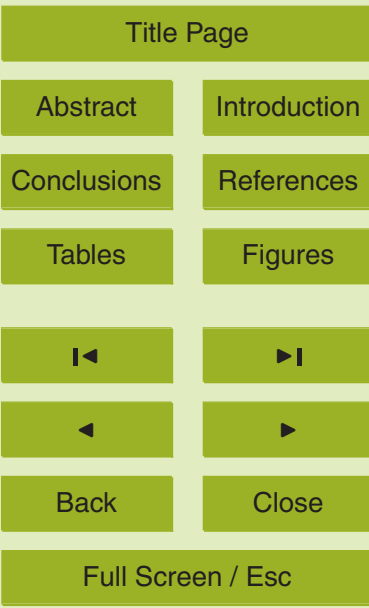

Printer-friendly Version

Interactive Discussion 


\section{BGD}

9, 3515-3544, 2012

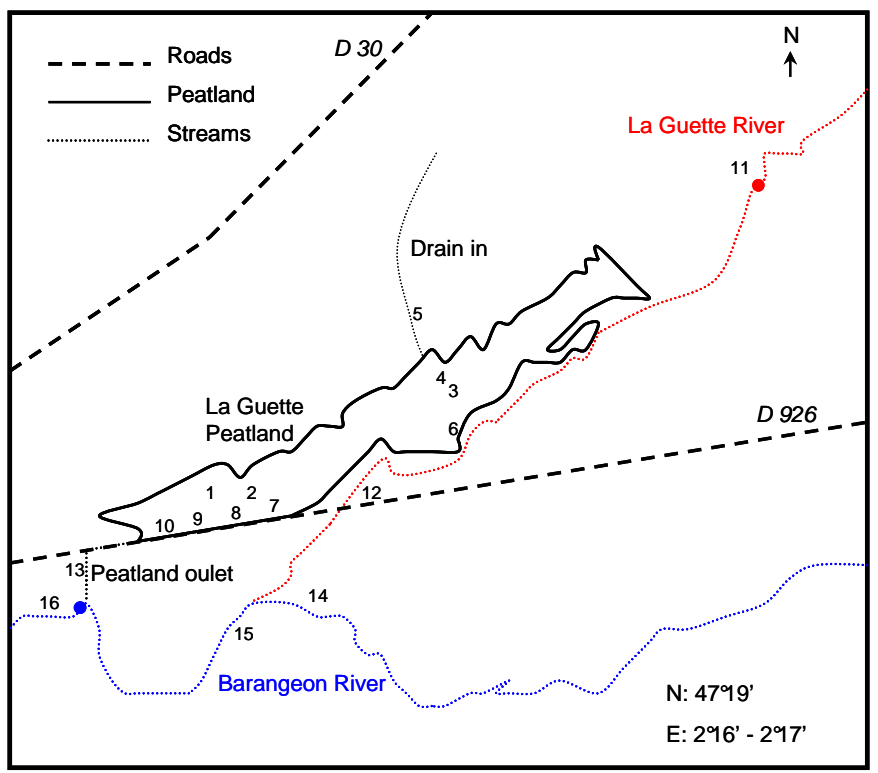

\section{Dissolved carbon concentrations in a peatland-stream continuum}

S. Gogo et al.

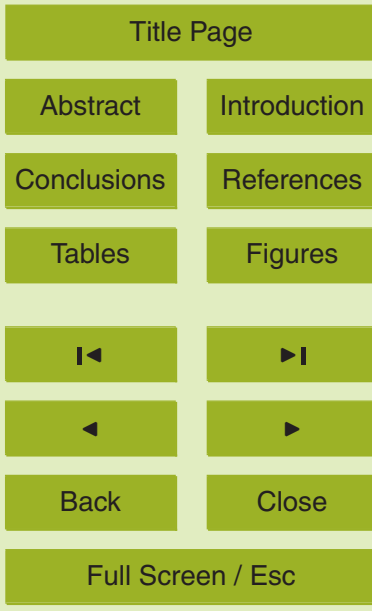

Printer-friendly Version

Interactive Discussion

Fig. 1. Map of the La Guette peatland and sampling points. The red dot corresponds to the upstream La Guette river (sample point taken as a reference for stream water characteristics) and the blue dot corresponds to the downstream Barangeon river (the river sampling point that may be influenced by peatland waters). The colour code is the same as Fig. 4 . 


\section{BGD}

9, 3515-3544, 2012

\section{Dissolved carbon concentrations in a peatland-stream continuum}
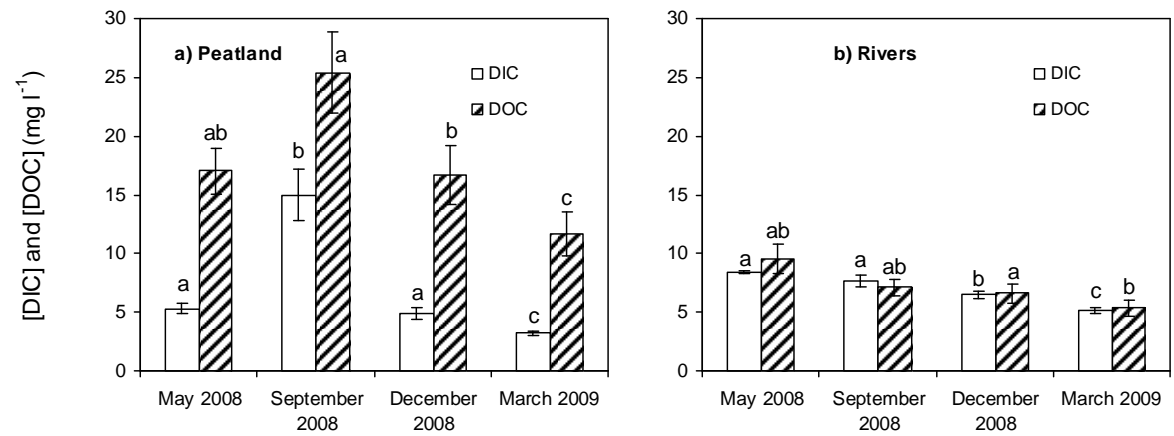

S. Gogo et al.

Fig. 2. Average DIC and DOC concentrations at each sampling time in (a) the peatland water $(n=9)$ and in (b) the streams ( $n=4$ in May and September, $n=6$ in December and March). Different letters indicate significant differences $(P>0.05)$.

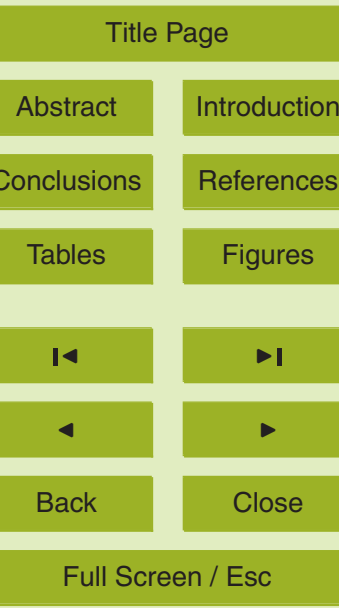

Printer-friendly Version

Interactive Discussion 
BGD

9, 3515-3544, 2012

\section{Dissolved carbon} concentrations in a peatland-stream continuum
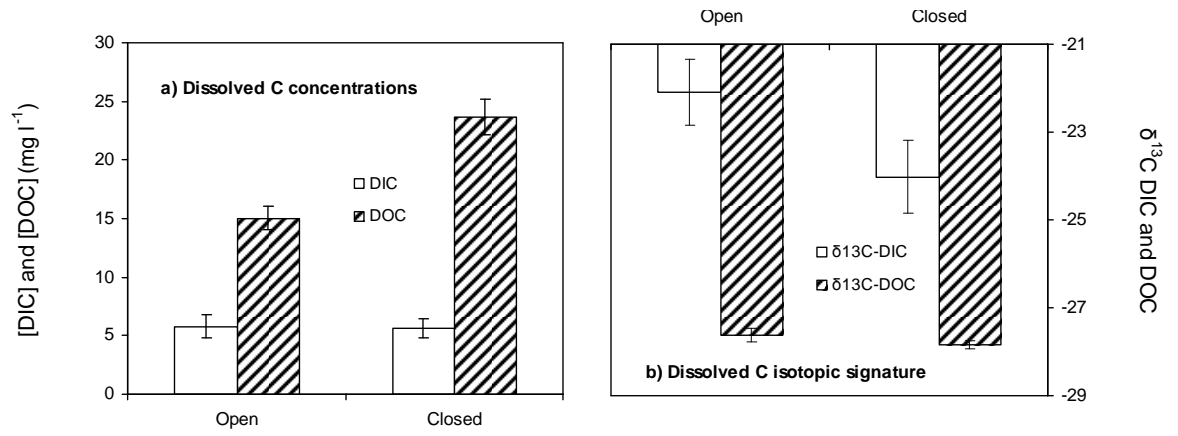

Fig. 3. Average DIC and DOC concentrations (a) and $\delta^{13} \mathrm{C}(\mathbf{b})$ in open and closed vegetation $(n=8)$.

Title Page
S. Gogo et al.

\section{Abstract}

Conclusions

Tables

14

Back
Introduction

References

Figures

$\rightarrow$

$>$

Close

\section{Full Screen / Esc}

Printer-friendly Version

Interactive Discussion 


\section{BGD}

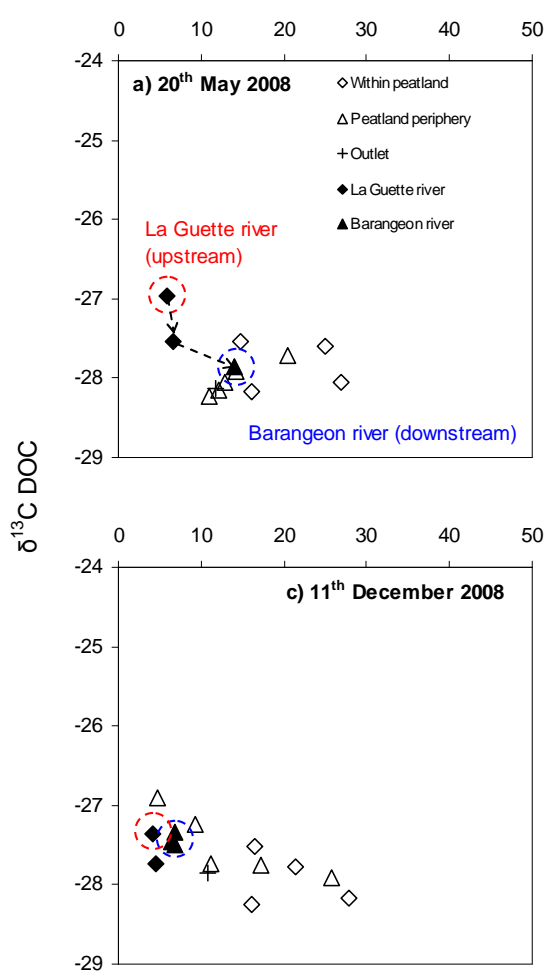
S. Gogo et al.

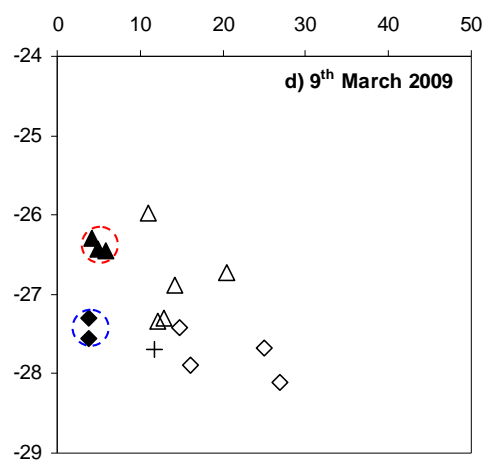

Title Page

Abstract

Conclusions

Tables

14

4

9, 3515-3544, 2012

\section{Dissolved carbon concentrations in a peatland-stream continuum}

Introduction

References

Figures

$\rightarrow$ I

Back

Close

Full Screen / Esc

Fig. 4. Seasonal and spatial variation of the relationship of the $D O C$ isotopic signature and concentration. The red circles correspond to the upstream La Guette river sample and the blue circles correspond to the downstream Barangeon river sample.

Printer-friendly Version

Interactive Discussion 
ePCO$=$ ratio $P \mathrm{CO}_{2}$ water $: P \mathrm{CO}_{2}$ air $\left(P \mathrm{CO}_{2}\right.$ air $\left.=378 \mathrm{ppm}\right)$

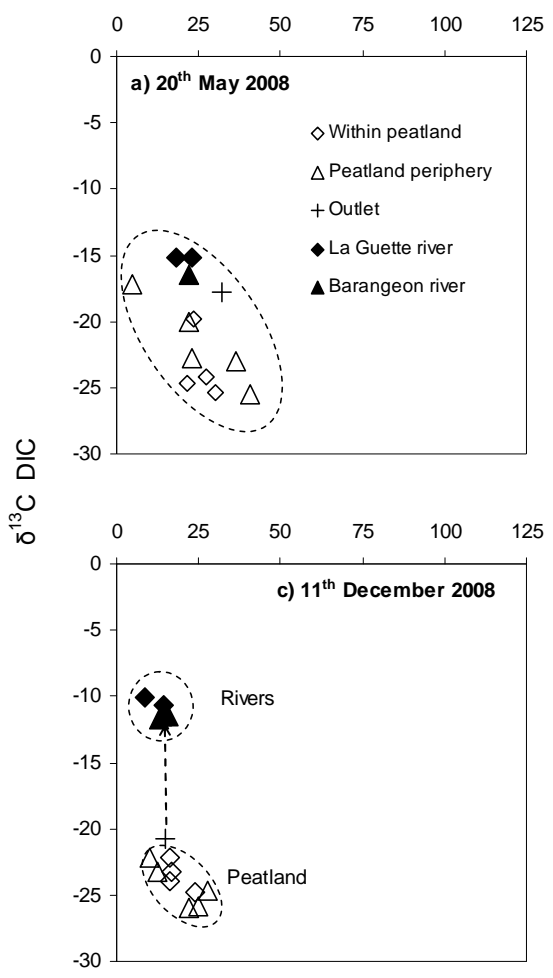

BGD

9, 3515-3544, 2012

Dissolved carbon concentrations in a peatland-stream continuum
S. Gogo et al.

Title Page

Abstract

Introduction

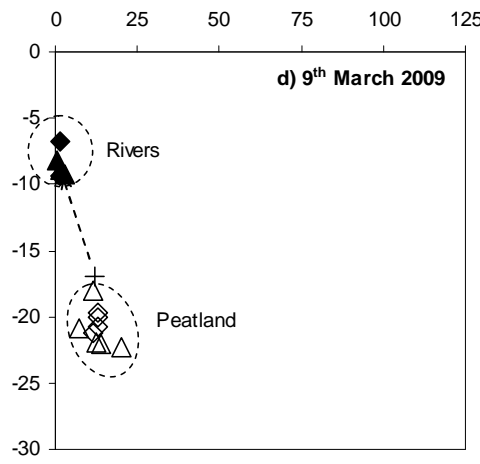

Conclusions

References

Tables

Figures

14

4

Back

Close

Full Screen / Esc

Printer-friendly Version

Interactive Discussion 


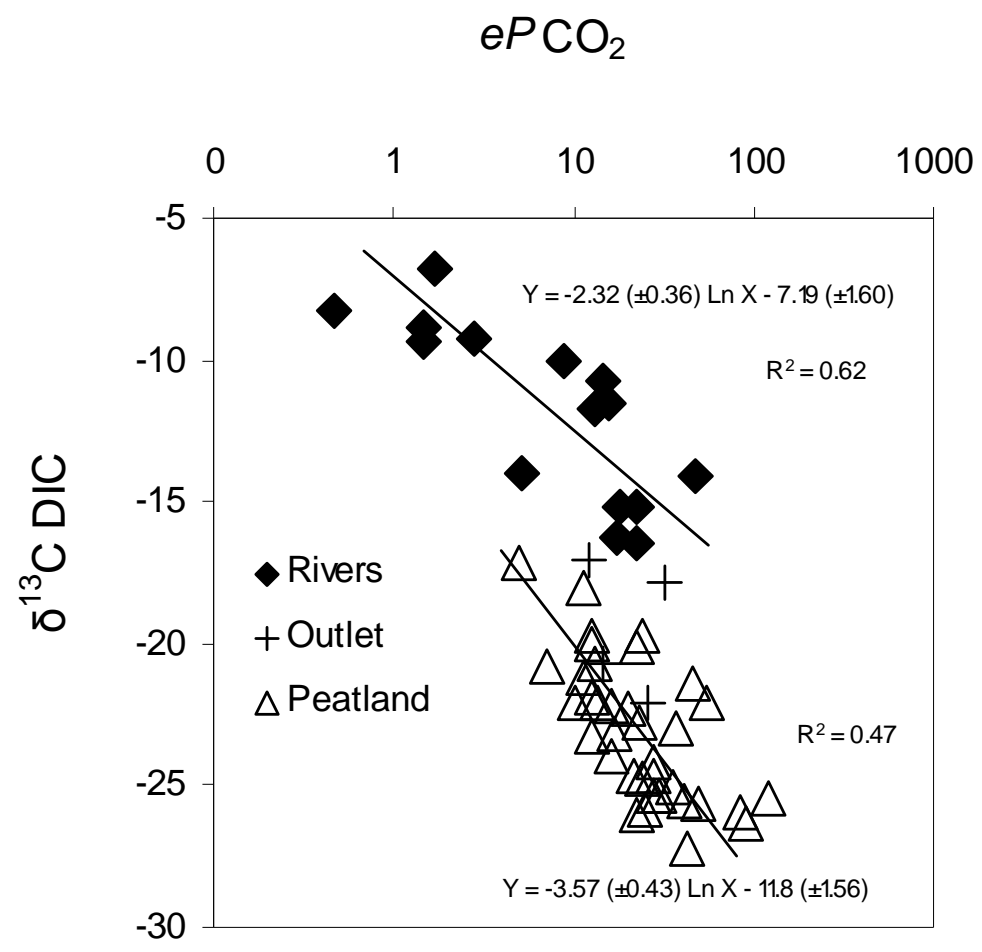

9, 3515-3544, 2012

\section{Dissolved carbon concentrations in a peatland-stream continuum}
S. Gogo et al.

Title Page

Abstract

Introduction

Conclusions

References

Tables

Figures

14

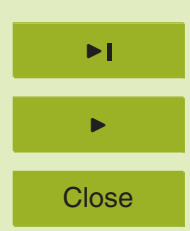

Back

Close

Full Screen / Esc

Fig. 6. Relationship between the natural Log of the excess of dissolved $\mathrm{CO}_{2}$ and the DIC isotopic signature (closed diamonds = river samples, cross $=$ outlet, open triangle $=$ peatland samples). Regression lines were calculated with the model II regression.

Printer-friendly Version

Interactive Discussion 
BGD

9, 3515-3544, 2012

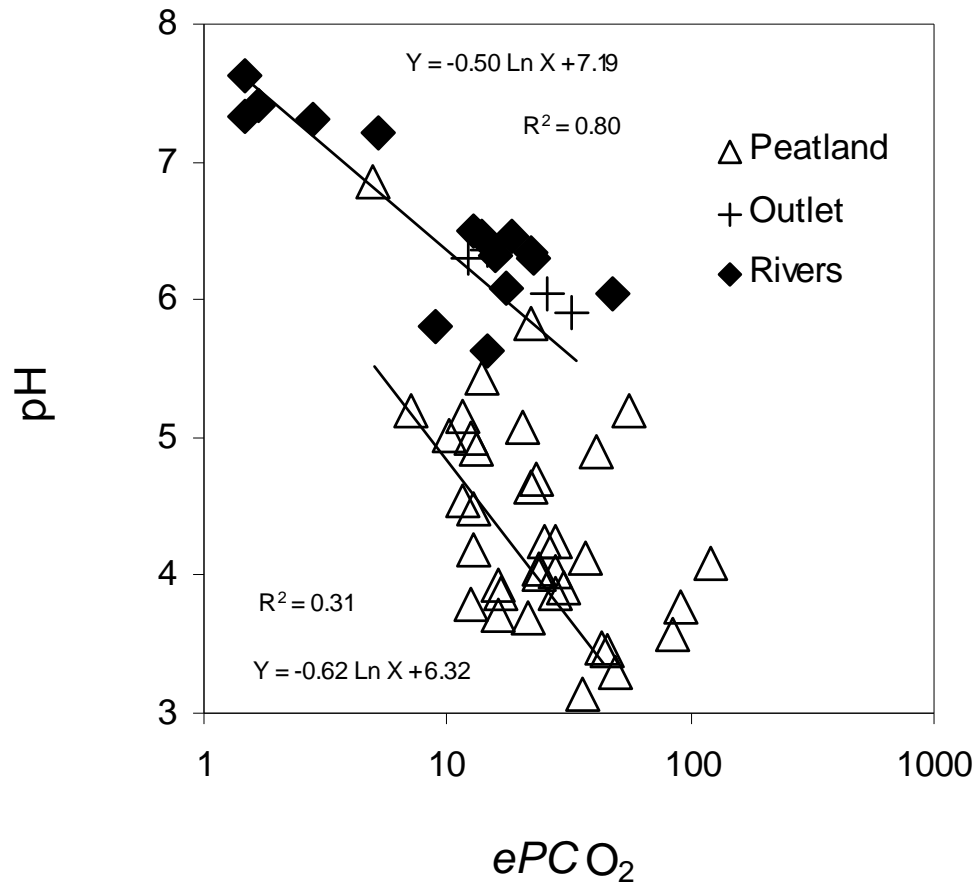

Fig. 7. Relationship between the natural Log of the excess of dissolved $\mathrm{CO}_{2}$ and the $\mathrm{pH}$ (closed diamonds $=$ river samples, cross $=$ outlet, open triangle $=$ peatland samples). Regression lines were calculated with the model II regression.

\section{Dissolved carbon concentrations in a peatland-stream continuum}

S. Gogo et al.

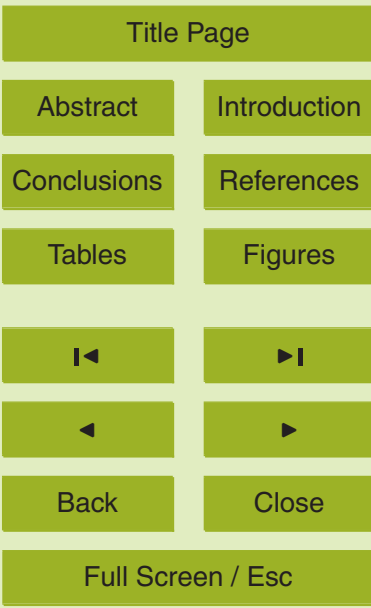

Printer-friendly Version

Interactive Discussion 
BGD

9, 3515-3544, 2012

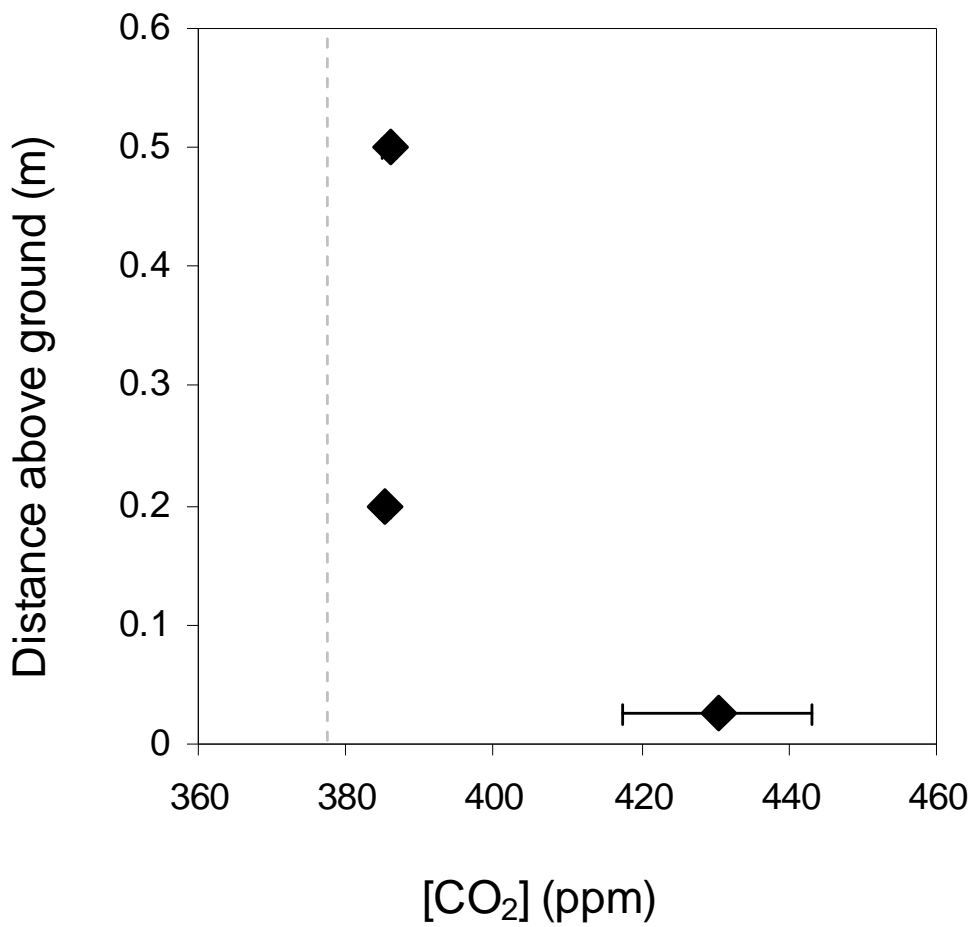

Fig. 8. $\mathrm{CO}_{2}$ partial pressure (in ppm) in air above the peatland ground in a Molina caerulea -Ericaceous shrub vegetation $(n=3)$. The dotted line represent a mean atmospheric $\mathrm{CO}_{2}$ concentration (378 ppm).

\section{Dissolved carbon concentrations in a peatland-stream continuum}

S. Gogo et al.

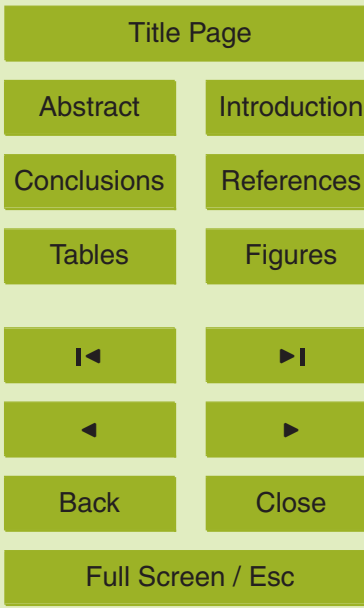

Printer-friendly Version

Interactive Discussion 